Original Article

\title{
Pathogenetic trial of boric acid in bean and tomato plants
}

\author{
Solange Monteiro de Toledo Piza Gomes Carneiro ${ }^{1}$, \\ Euclides Davidson Bueno Romanoํㅜ, Tiago Henrique dos Santos Garbim¹, \\ Bruno Garcia de Oliveira ${ }^{1}$, Marcus Zulian Teixeira ${ }^{2}$
}

(1) Agronomic Institute of Paraná, IAPAR, PR, Brazil

(2) Medical School of University of São Paulo, FMUSP, SP, Brazil

\begin{abstract}
Background: homeopathy is held in organic agriculture as a means to control disease and plagues. However, different from doctors, who have works on materia medica and repertories available to choose the most suitable homeopathic medicine for each patient, agronomists do not yet have an equivalent Homeopathic Materia Medica of Plants (HMMP) describing symptoms observed in plants. Aim: the aim of this study was to carry out a homeopathic pathogenetic trial (HPT) in plants comparing the effects elicited by boric acid in ponderable dose and dilution $6 \mathrm{cH}$ in two different plant species, namely bean and tomato cultivars. Methods: 4 tests were carried out, 2 on tomato and 2 on bean plants, which received 1 to 6 applications of treatments. Results: there were differences between both species regarding their sensitiveness to boric acid. None of the tomato plants that received Boron $6 \mathrm{cH}$ showed symptoms, differently from bean plants. On the other hand, in tests of ponderable doses of boric acid, tomato plants exhibited 3 symptoms more than bean plants. A higher number of bean plants exhibited symptoms with boric acid in ponderable dose than in dilution $6 \mathrm{cH}$ ). Nos ensaios com feijoeiro, um maior número de plantas apresentou sintomas após o tratamento com ácido bórico na dose ponderal do que com ácido bórico $6 \mathrm{cH}$. Conclusions: these results suggest that the elaboration of a HMMP must take into account the species in which symptoms were obtained. Moreover, HPTs in plants must be carried out with both ponderable doses and high dilutions in order for differences in sensitiveness among species be better identified.
\end{abstract}

Palavras-chave: Phaseolus vulgaris, Solanum lycopersicum, Homeopathic pathogenetic trial.

\section{Introduction}

Since the publication in 1999 of Normative Instruction No 7 by Brazilian Ministry of Agriculture [1], homeopathy is rated a practice suitable for the control of disease and plagues in organic agriculture. However, different from the case of doctors, who have works on materia medica and repertories available for the choice of the most suitable homeopathic medicine for each patient, agronomists do not have an equivalent Homeopathic Materia Medica of Plants (HMMP) describing symptoms obtained in plants. For this reason, as a rule, the choice of homeopathic remedies for plants has been grounded on analogies with the medical materia medica [2]. If on the one hand, this allowed for a quick application of homeopathy in agriculture, on the other it does not take into account the typical symptoms exhibited by plants and that naturally are remarkably different from the ones of human beings. 
The guidelines laid out in Organon of medicine [3] regarding homeopathic pathogenetic trials (HPTs) make explicit the need to learn the true pathogenetic power of drugs ("pure effects of medicines") through tests on individuals in which they will be used ("to constitute an artificial disease as similar as possible to the totality of the main symptoms of the natural disease to be healed"). To illustrate, $§ 105$ establishes that "the second point of the business of a true physician related to acquiring a knowledge of the instruments intended for the cure of the natural diseases, investigating the pathogenetic power of the medicines, in order, when called on to cure, to be able to select from among them one, from the list of whose symptoms an artificial disease may be constructed, as similar as possible to the totality of the principal symptoms of the natural disease sought to be cured". In $\S 106$ it is stated: "The whole pathogenetic effect of the several medicines must be known; that is to say, all the morbid symptoms and alterations in the health that each of them is specially capable of developing in the healthy individual must first have been observed as far as possible, before we can hope to be able to find among them, and to select, suitable homoeopathic remedies for most of the natural disease"[3].

In this way HPTs in plants can be a significant contribution to the development of homeopathy in agriculture $[4,5]$, since it will allow applying the principle of similitude on the grounds of the characteristic symptoms of plants.

Plants with agricultural interest belong to different botanic genera and species, and such diversity might lead to different pathogenetic symptoms. The homeopathic pure materia medica reports the doses used in HPTs, the frequency of intake of drugs and when available, also data stemming from intoxications. Moreover, it is recorded the name of volunteers and the symptoms exhibited by each one of them [6]. Making a parallel with plants, the structure of a HMMP ought to take into account the symptoms exhibited by different families and species of plants after taking some drug in, as well as (ponderable and high-diluted) the corresponding doses and frequency of application. Many plant species and cultivars show differences in their sensitiveness to the toxicity of mineral elements [7-10] a fact that can be advantageously used in the elaboration of a HMMP.

Boron (B) is a micronutrient essential for the growth of plants. It regulates the activity of the cell membrane, the rate of cell development, cell division, the synthesis of proteins and the transportation of carbohydrates from the leaves to other organs $[7,11]$. Since it is a substance used in agriculture, it is important to assess the relative sensitiveness of different species of plants subjected to HPTs of boron in ponderable and high-diluted doses.

In this way, the aim of this study was to carry out a HPT on plants by comparing the symptoms exhibited by bean and tomato cultivars after the administration of boric acid in ponderable dose and dilution $6 \mathrm{cH}$.

\section{Materials and Methods}

Four tests were carried out, 2 in tomato and 2 in bean plants.

HPT in tomato plants: tests were carried out in a greenhouse, with one plant per vase. Variety chosen was Santa Clara Miss Brasil. The application of the treatments started when plants had shown the fourth leaf. The experimental design was entirely randomized, with 7 treatments and 4 repetitions (1 plant per repetition) in tests with ponderable dose and 10 repetitions in tests with high dilution. Treatments consisted in a number of spray applications of boric acid every 4 to 6 days. Plants subjected to treatment 1 received only one application, treatment 2, 2 applications and so on up to 6 applications. Plants receiving control treatment were treated only with purified water in spray application in 6 different days similarly to treatment 6 . Equipment for application was a $500 \mathrm{ml}$ hand-operated sprayer, and each treatment had your own device. Spraying in all treatments continued until running down. In order to avoid contamination during spraying, treatments were carried out separately in a different room of the greenhouse. Assessment was accomplished 
through the description of the observed symptoms according to Honey's classification [12]. Solutions were prepared with boric acid in concentration $74.16 \mathrm{mg} / 100 \mathrm{ml}$ purified water. In the first test, plants were applied boric acid in ponderable dose and in the second test diluted and agitated boric acid. In the latter, the solution of boric acid $74.16 \mathrm{mg} / 100 \mathrm{ml}$ was prepared following the Hahnemannian centesimal scale [13] in purified water. Dilution $6 \mathrm{cH}$ was used in this study and it was prepared on the same day it was applied, after being agitated further 30 times in the greenhouse before application.

HPT in bean plants: the design of both tests in bean plants was the same as in tomato plants. Cultivar used was "Carioca", which has undetermined growth habit, matted light chestnut hued seeds and havana hued streaks. It was sowed 1 plant per vase. The test began when the third trifoliate leave was fully developed.

\section{Results}

Plants that received control treatment (purified water) in all tests showed no symptoms. Symptoms observed occurred in the leaves of plants treated with boric acid (Table 1), whereas in test "tomato-6cH" no plant exhibited any symptom whatsoever.

Table 1: description and occurrence of symptoms in plants per treatment

\begin{tabular}{|c|c|c|c|c|c|c|c|c|c|c|c|c|c|c|c|c|c|c|}
\hline \multirow[b]{3}{*}{ Leaf symptom } & \multicolumn{18}{|c|}{ Percentage of plants in each treatment exhibiting symptoms } \\
\hline & \multicolumn{6}{|c|}{ mato plants - ponderable dose } & \multicolumn{6}{|c|}{ Bean plants - ponderable dose } & \multicolumn{6}{|c|}{ Bean plants- $6 \mathrm{cH}$} \\
\hline & T1 & T2 & T3 & T4 & T5 & T6 & T1 & T2 & T3 & T4 & T5 & T6 & T1 & T2 & T3 & T4 & T5 & T6 \\
\hline $\begin{array}{l}\text { - Irregular necrotic lesion } \\
\text { - cream }\end{array}$ & 25 & 25 & 0 & 25 & 25 & 25 & 0 & 0 & 0 & 0 & 0 & 0 & 0 & 0 & 0 & 0 & 0 & 0 \\
\hline $\begin{array}{l}\text { - Irregular necrotic lesion } \\
\text { - light chestnut }\end{array}$ & 50 & 100 & 100 & 100 & 100 & 100 & 75 & 75 & 75 & 100 & 75 & 100 & 10 & 40 & 30 & 20 & 40 & 20 \\
\hline $\begin{array}{l}\text { - Irregular necrotic lesion } \\
\text { - dark chestnut }\end{array}$ & 75 & 50 & 75 & 100 & 100 & 100 & 75 & 100 & 100 & 100 & 100 & 100 & 10 & 0 & 40 & 20 & 30 & 10 \\
\hline $\begin{array}{l}- \text { Localization of necrotic lesions } \\
\text { - margin of foliole }\end{array}$ & 100 & 100 & 100 & 100 & 100 & 100 & 100 & 100 & 100 & 100 & 100 & 100 & 0 & 20 & 40 & 30 & 30 & 10 \\
\hline $\begin{array}{l}\text { - Localization of necrotic lesion } \\
\text { - side of foliole }\end{array}$ & 100 & 100 & 100 & 100 & 100 & 100 & 75 & 100 & 100 & 75 & 100 & 100 & 10 & 30 & 30 & 20 & 30 & 10 \\
\hline - Chlorosis around necrosis & 75 & 100 & 100 & 100 & 100 & 100 & 75 & 100 & 100 & 100 & 100 & 100 & 0 & 0 & 10 & 0 & 20 & 0 \\
\hline - Necrosis on the tips of folioles & 100 & 100 & 100 & 100 & 100 & 100 & 100 & 100 & 100 & 100 & 100 & 100 & 0 & 10 & 30 & 10 & 0 & 0 \\
\hline - Light-green islands in foliar tissue & 0 & 100 & 75 & 100 & 75 & 25 & 0 & 0 & 0 & 0 & 0 & 0 & 0 & 0 & 0 & 0 & 0 & 0 \\
\hline - Epinasty & 0 & 0 & 0 & 75 & 75 & 0 & 0 & 0 & 0 & 0 & 0 & 0 & 0 & 0 & 0 & 0 & 0 & 0 \\
\hline
\end{tabular}


In tests with boric acid in ponderable doses, all bean (Figure 1) and tomato (Figure 2) plants in treatments 1 to 6 exhibited at least 1 symptom, while in several cases one same plant exhibited more than one symptom.

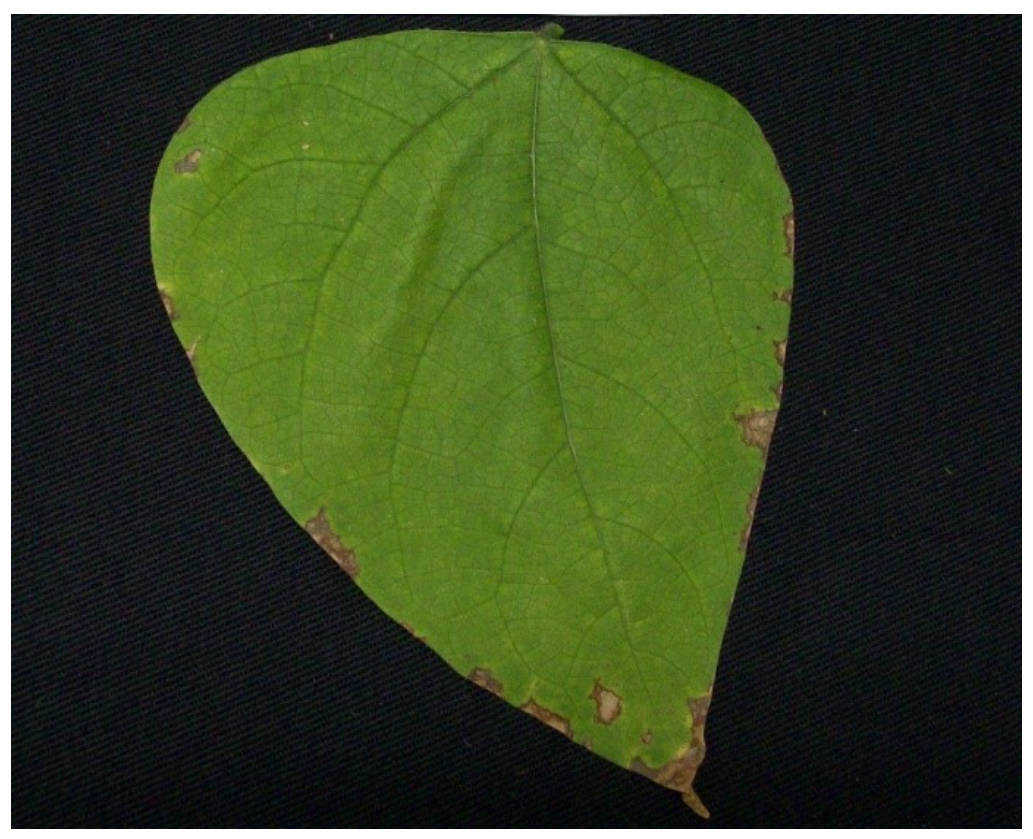

Figure 1: Necrotic lesion in bean plant

The 2 species studied differed regarding sensitiveness to boric acid not only in dilution $6 \mathrm{cH}$ but also in ponderable dose, since tomato plants exhibited 3 symptoms more than bean plants: cream-hued necrotic lesion, light-green islands and epinasty. Regarding the remainder of symptoms, rate of occurrence was similar among all plants under study.

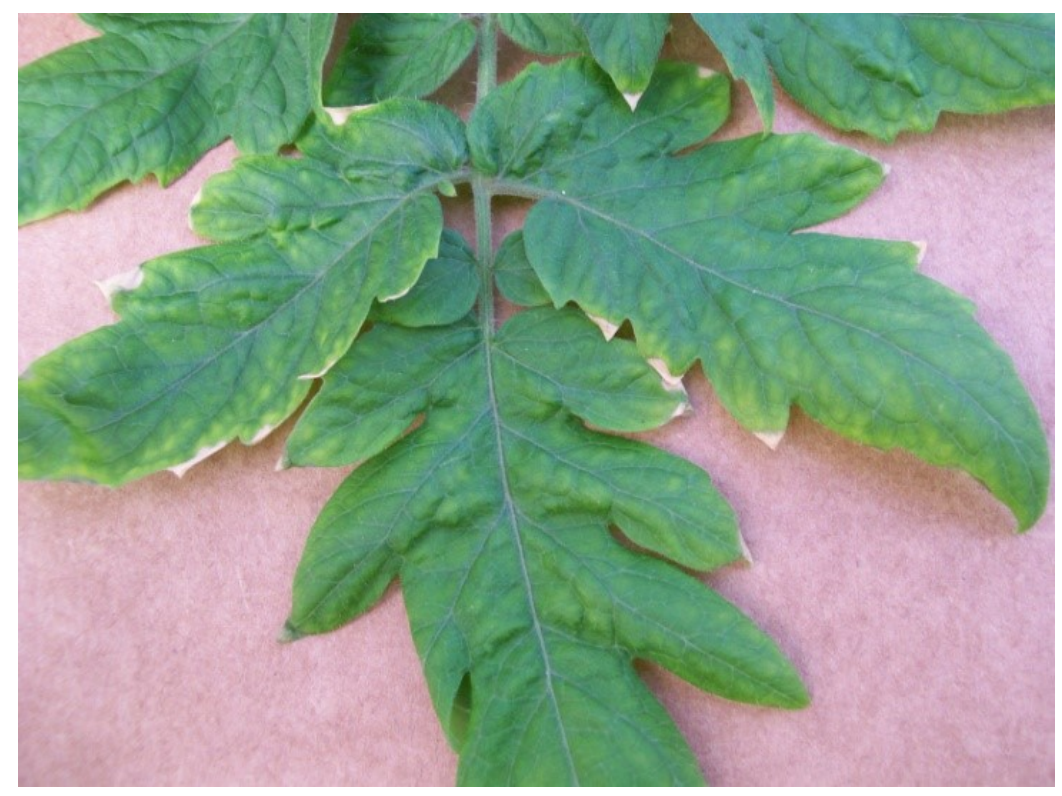

Figura 2: Necrosis on the tips of tomatoes folioles.

Similar to test "bean plant - ponderable dose", also samples in test "bean plant - 6cH" did not exhibited symptoms cream-hued necrotic lesion, light-green islands and epinasty. The percentage of plants exhibiting 
symptoms in test "bean plant - 6cH" was much lower than in test "bean plant - ponderable dose" (Table 2) particularly regarding symptoms "chlorosis around necrosis"and "necrosis on the tips of folioles". No symptom that was not observed with ponderable dose was observed in tests with $6 \mathrm{cH}$.

Table 2 - Occurrence of symptoms in all treated plants

\begin{tabular}{|l|c|c|c|}
\hline Leaf symptom & $\begin{array}{c}\text { Tomato plants } \\
\text { (ponderable dose) }\end{array}$ & $\begin{array}{c}\text { Bean plants } \\
\text { (ponderable dose })\end{array}$ & $\begin{array}{c}\text { Bean plants } \\
\mathbf{6 c H})\end{array}$ \\
\hline $\begin{array}{l}\text { - Irregular necrotic lesion } \\
\text { - cream }\end{array}$ & $5(20,8)$ & 0 & 0 \\
\hline $\begin{array}{l}\text { - Irregular necrotic lesion } \\
\text { - light chestnut }\end{array}$ & $22(91,6)$ & $20(83,3)$ & $16(26,6)$ \\
\hline $\begin{array}{l}\text { - Irregular necrotic lesion } \\
\text { - dark chestnut }\end{array}$ & $20(83,3)$ & $23(95,8)$ & $11(18,3)$ \\
\hline $\begin{array}{l}\text { - Localization of necrotic lesions } \\
\text { - margin of foliole }\end{array}$ & $24(100)$ & $24(100)$ & $13(21,6)$ \\
\hline - Localization of necrotic lesion & $24(100)$ & $22(91,6)$ & $13(21,6)$ \\
\hline side of foliole & $23(95,8)$ & $23(95,8)$ & $3(5,0)$ \\
\hline - Chlorosis around necrosis & $24(100)$ & $24(100)$ & $5(8,3)$ \\
\hline - Necrosis on the tips of folioles & $15(62,5)$ & 0 & 0 \\
\hline - Light-green islands in foliar tissue & $6(25,0)$ & 0 & 0 \\
\hline - Epinasty & & & \\
\hline
\end{tabular}

\section{Discussion}

Necrotic spots and mottled chlorosis are symptoms of toxicity by boron, and they appear on the areas of leaves with most transpiration [11]. Differences in sensitiveness to boron among plant species have been reported in the literature. Cereals and gramineous plants are more sensitive to high levels of boron. Barley has the highest sensitiveness followed by wheat and oat [7], whereas cotton and sorghum are rated quite tolerant [14]. In this study, it was observed a higher sensitiveness to boron in ponderable dose in tomato plants, which exhibited 3 symptoms more than bean plants.

Besides differences in sensitiveness to boron among different species of plants, it was also observed differences among cultivars of a same species. Carneiro et al [15] found that 3 cultivars of bean plants reacted in different manners to intoxication with boric acid. Eldorado cultivar always showed a lesser number of symptoms independently from the dose employed, whereas Uirapuru and Carioca cultivars were more sensitive. Such differentiated sensitiveness has been reported in the literature also for other species of plants $[16,17]$.

Ours is the first report of differences in sensitiveness between species to high dilutions of boron. Tomato plants showed no symptoms when treated with dilution $6 \mathrm{cH}$, whereas bean plants exhibited the same kind of symptoms as when treated with ponderable dose although in a lesser number of samples. Rossi et al [18] 
studied the effect of homeopathic preparations on the productivity of potatoes. These authors observed that out of 3 cultivars tested, only 1 was affected by the homeopathic preparation. In our study only 1 cultivar of each species was used, therefore it cannot be established whether the lack of symptoms in test "tomato plant $6 \mathrm{cH}$ " was due to the specificity of the cultivar employed or whether it is a general trait of tomato plants.

In this study, only primary symptoms developed in foliar tissues were observed and to describe them the symptomatology presented by Salgado and Amorim [12] proved to be adequate. However, it is possible that other alterations also occurred but were not visually detected. Plants have an ability to react through metabolic changes that are not visually detectable [19]. Some authors have reported changes in the contents of secondary metabolites in plants elicited by high-diluted substances [20-22]. However, taking into account that the choice of the homeopathic medicine most suitable to a farm/culture/crop will depend on the visual identification of symptoms in plants at the field, we did not hold necessary to evaluate in this study alterations not visually identifiable.

The results observed in this study together with data in the literature regarding differences in symptoms of intoxication among plant species and cultivars [7-10,14-17] can be used in the elaboration of a HMMP describing the typical symptoms exhibited by plants [23]. Such HMMP grounded on the symptomatology of plants has the advantage of following Hahnemann's guidelines [3] in Organon §144: "From such a materia medica everything that is conjectural, all that is mere assertion or imaginary should be strictly excluded; everything should be the pure language of nature carefully and honestly interrogated".

Symptoms obtained in HPTs in plants as grounds for a therapeutic application of the principle of similitude have already been employed by Betti et al [24] to increase the resistance of tobacco to TMV. The differences in the response to intoxication by a given substance among different species of plants described in the literature and in this study regarding the pathogenetic experimentation of boric acid and more particularly of Boron $6 \mathrm{cH}$ strengthen the need to test substances in the individuals/species where they will be used for therapeutic purposes according to the principle of similitude. Moreover, from these results it is possible to infer that the indication of homeopathic medicines will have to take into account such differences due to the requirement of individualization of treatment. Further studies are needed to verify this hypothesis.

The results presented in this article suggest that the elaboration of a HMMP requires taking notice of the species where symptoms were obtained. Another significant point is that HPTs in plants ought to be carried with both ponderable doses and high dilutions in order to identify more clearly differences in sensitiveness among species, and a larger number of symptoms can be observed and recorded, thereby allowing for a more accurate application of therapeutic similitude in each botanical species. In this way, it will be possible to score the relative significance of each symptom for a given drug as it is done in the traditional homeopathic materia medica.

\section{References}

[1] Brasil. Ministério da Agricultura, Pecuária e Abastecimento. Instrução normativa nº 7, 1999. [cited 2010 July 30]; Available from: http://extranet.agricultura.gov.br/sislegis$\underline{\text { consulta/consultarlegislacao.do?operacao=visualizar\&id }=1662}$

[2] Bonato CM. Homeopatia em vegetais. Cultura Homeopática. 2007; 6(21):24-28.

[3] Hahnemann's. Organon da arte de curar. 2001. $6^{a}$ ed. Robe Editorial, São Paulo. 248p. 
[4] Teixeira MZ. Pesquisa básica em homeopatia: revisão bibliográfica. Revista de Homeopatia. 2001; 66(2): 526.

[5] Carneiro SMTPG, Teixeira MZ. Pesquisa homeopática na agricultura: premissas básicas. Revista de Homeopatia. 2003; 68 (1-2): 63-73.

[6] Hahnemann S. Materia Medica Pura. New Delhi: B. Jain Publishers; 1994.

[7] Ministério da Agricultura. Ficha técnica do solo. Boron for field crops. British Columbia, 1991. [cited 2007 May 07]; Avalialable from http://www.al.gov.bc.ca/ resmgmt/publist/600series/631012-1.pdf

[8] Brown PH and HU H. Better Crops. Department of Pomology, University of California, Davis. Boron Mobility and Consequent Management in Different Crops. 1998; 82(2):28-31. [cited 2007 May 22]; Available from http://www.ppi-ppic.org/ppiweb/bcrops.nsf/\$webindex/DA85FEC304910258852568F0006CF59C/\$file/982p28.pdf

[9] Wheeler DM, Edmeades DC, Christie RA, Gardner R. Effect of aluminium on the growth of 34 plant species: a summary of results obtained in low ionic strength solution culture. Plant and Soil. 1992; 146(1-2): 61-66.

[10] Souza Jr JO, Fernandes RBA, Neves JCL, Chagas JM. Triagem de variedades de feijão visando à tolerância ao manganês. Revista Ceres. 1996; 43(250):697-706.

[11] Malavolta E. Elementos de nutrição mineral de plantas. São Paulo: Ed. Agronômica Ceres;1980. 251p.

[12] Salgado C, Amorim L. Sintomatologia. In: Bergamin Filho A, Kimati H, Amorim L. Manual de Fitopatologia: princípios e conceitos. São Paulo: Ed. Agronômica Ceres; 1995. Cap10, p.212-223.

[13] Farmacopéia Homeopática Brasileira. 2th ed. São Paulo: Atheneu; 1997.

[14] Califórnia. Water quality objectives. Capítulo VI. Implementação. Califórnia, 2000. [cited 2007 March 19]; Available from http://www.swrcb.ca.gov/rwwcb5/water_issues/basin_plans/salt_boron/staffreport.pdf.

[15] Carneiro SMTPG, Garbim TS, Romano EDB, Oliveira BG. Estudo comparativo da intoxicação por ácido bórico em três cultivares de feijoeiro (phaseolus vulgaris 1.) II Simpósio de Conservação do norte do Paraná e IV Encontro de Biologia e Iniciação Cientifica - Universidade Estadual do Norte do Paraná - UENP. 2010. Cd room [prooceedings]. 13 a 17 de setembro de 2010 - UENP Cornélio Procópio.

[16] Punchana S, Jamjod S, Rerkasem B. Response to boron toxicity in boron efficient and inefficient wheat genotypes. Proceedings of the 4th international crop science congress, 2004. [cited 2010 August 12]; Available from http://www.cropscience.org.au/icsc2004/poster/2/5/5/899_punchanas.htm\#topofpage

[17] Paull JG, Rathjen AJ, Cartwright B. Major gene control of tolerance of bread wheat (triticum aestivum 1.) to high concentrations of soil boron. Euphytica. 1991; 55:217-228.

[18] Rossi F, Azevedo Filho JA, Melo PCT, Ambrosano EJ, Guirado N, Schammass EA. Cultivo orgânico de batata com aplicação de preparados homeopáticos. Revista Brasileira de Agroecologia. 2007; 2(2): 937-940.

[19] Rossi F, Ambrosano EJ, Rolim PRR, von Atzinguem EMM, Silva NMA. Fitopatogenesia. Cultura Homeopática. 2006; 5(16). 
[20] Carvalho LM, Casali VWD, Cecon PR, Souza MA, Lisboa SP. Efeito de potências decimais da homeopatia de arnica montana sobre plantas de artemísia. Revista Brasileira de Plantas Medicinais. 2003; 6(1): 46-50.

[21] Carvalho LM, Casali VWD, Lisboa SP, Souza MA, Cecon PR. Efeito da homeopatia arnica montana, nas potências centesimais, sobre plantas de artemísia. Revista Brasileira de Plantas Medicinais. 2005; 7(3):33-36.

[22] Bonato CM, Proença GT, Reis B. Homeopathic drugs arsenicum album and sulphur affect the growth and essential oil content in mint (mentha arvensis 1.). Acta scientiarum Agronomy. 2009; 31 (1): 101-105.

[23] Carneiro SMTPG, Oliveira BG, Garbim THS, Teixeira MZ. Matéria Médica Homeopática das Plantas: boro, manganês e zinco. In: homeopatia: princípios e aplicação na agroecologia. Londrina: IAPAR; 2011. No prelo.

[24] Betti L, Lazzarato L, Trebbi G, Brizzi M, Calzoni GL, Borghini F, Nani D. Effects of homeopathic arsenic on tobacco plant resistance to tobacco mosaic virus. Theoretical suggestions about system variability, based on a large experimental data set. Homeopathy. 2003; 92: 195-202.

\title{
Experimentação patogenética de ácido bórico em tomateiros e feijoeiros.
}

\author{
RESUMO
}

Introdução: A homeopatia é considerada como uma prática para manejo de doenças e pragas na agricultura orgânica. No entanto, ao contrário dos médicos que dispõe das Matérias Médicas e Repertórios para a escolha do medicamento homeopático mais adequado para o paciente, os agrônomos não dispõem de uma Matéria Médica Homeopática de Plantas (MMHP) com sintomas observados em vegetais. Objetivos: O objetivo deste trabalho foi realizar uma experimentação patogenética homeopática em vegetais, comparando os sintomas apresentados por uma cultivar de feijoeiro e uma cultivar de tomateiro após a administração de ácido bórico em dose ponderal e na dinamização 6cH. Métodos: Foram conduzidos quatro experimentos, dois com tomateiro e dois com feijoeiro, sendo que as plantas receberam entre uma a seis pulverizações dos tratamentos. Resultados: Observaram-se diferenças entre as espécies quanto à sensibilidade ao ácido bórico: nenhuma planta de tomateiro que recebeu Boro $6 \mathrm{cH}$ apresentou sintomas, diferentemente do feijoeiro. Por outro lado, nos ensaios com ácido bórico em dose ponderal o tomateiro apresentou três sintomas a mais que o feijoeiro. Nos ensaios com feijoeiro, um maior número de plantas apresentou sintomas após o tratamento com ácido bórico na dose ponderal do que com ácido bórico $6 \mathrm{cH}$. Conclusões: Estes resultados sugerem que na elaboração de uma Matéria Médica Homeopática de Plantas (MMHP) deve ser considerada a espécie vegetal na qual os sintomas foram obtidos. Além disso, as experimentações patogenéticas homeopáticas em vegetais devem ser realizadas tanto com doses ponderais quanto com doses dinamizadas, a fim de que as diferenças na sensibilidade entre espécies possam ser mais bem detectadas.

Palavras-chave: Phaseolus vulgaris, Solanum lycopersicum, patogenesia, homeopatia.

\section{Experimentación patogenetica de ácido Bórico en tomateros y frijoleros} RESUMEN 
Introducción: La homeopatia es usada en la práctica para el manejo de enfermedades y plagas en la agricultura orgánica. Pero, al contrario de los médicos que disponen de Materias Médicas y Repertorios para la elección del medicamento homeopático mas adecuado para el paciente, los agrónomos no disponen de una Materia Médica Homeopática de Plantas (MMHP) com sintomas observados em vegetales. Objetivos: El objetivo de este trabajo fue realizar una experimentación patogenética homeopática en vegetales, comparando los sintomas presentes en un cultivo de frijoles y de tomates después de administrar ácido bórico en dosis ponderales y en la dinamización $6 \mathrm{CH}$. Métodos: fueron realizados cuatro experimentos, dos con tomateros y dos con frijoleros y las plantas recibieron seis pulverizaciones con las sustancias del tratamiento.Resultados: Seobservaron diferencias entre las espécies en relación a la sensibilidad al ácido bórico: ninguna planta de tomatero que recibió Boro $6 \mathrm{CH}$ presentó sintomas, al contrario de los frijoleros. Por outro lado en los ensayos con ácido bórico ponderal los tomateros presentaron tres sintomas más que los frijoleros. En los ensayos con frijoleros um mayor número de plantas presentó sintomas después del tratamiento con ácido bórico en la dosis ponderal en relación a los tratados com Boro $6 \mathrm{CH}$. Conclusión: estos resultados sugieren que en la elaboración de una Materia Médica Homeopática de Plantas (MMHP) debe ser considerada la espécie vegetal en la que los sintomas fueron obtenidos. Además, las experimentaciones patogenéticas homeopáticas en vegetales deben ser realizadas tanto con dosis ponderales como con dosis dinamizadas a fin de que las diferencias en la sensibilidad entre espécies puedan ser mejor detectadas..

Palabras-clave: Phaseolus vulgaris, Solanum lycopersicum, Experimentación patogenética homeopática.

\section{(c)) EY-NC-ND Licensed to GIRI}

Support: authors declare that this study received no funding

Conflict of interest: authors declare there is no conflict of interest

Received: 02 October 2011; Revised: 10 March 2011; Published: 30 March 2011.

Correspondence author: Solange Gomes Carneiro, solange_carneiro@iapar.br

How to cite this article: Carneiro SMTPG, Romano EDB, Garbim THS, Oliveira BG, Teixeira MZ. Pathogenetic trial of boric acid in bean and tomato plants. Int J High Dilution Res [online]. 2011 [cited YYYY Month dd]; 10(34):37-45. Available from: http://www.feg.unesp.br/ ojs/index.php/ijhdr/article/view/422/458 